\title{
Disaggregated Commitment Of Traders Data And Prospective Price Effects
}

Einar M. Often, Alpha Corporate Finance, Norway

Craig H. Wisen, University of Alaska Fairbanks, USA

\begin{abstract}
The interplay between speculative levels in futures contracts and prospective price changes is an important issue for hedgers, speculators, consumers, and regulators. The Commodity Futures Trading Commission (CFTC) began the dissemination of disaggregated data in September 2009; which allows for additional analysis that was previously not possible. This study analyzes Disaggregated Commitments of Traders data and prospective price effects in underlying futures markets. The relationship between position changes and subsequent price movements is examined through a series of Granger causality tests in agricultural commodity, energy, and metal markets. Primary findings indicate large traders and hedgers have more influence in future price changes in some commodity markets. In addition, there is limited evidence that changes in the positions of swap dealers and producers can cause subsequent futures prices to change, although the effect is inconsistent across time.
\end{abstract}

Keywords: Disaggregated Commitments of Traders; CFTC; Futures

\section{INTRODUCTION}

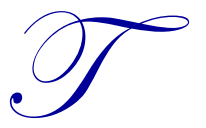

here is frequent speculation in academia and the media seeking to explain the sharp increases in many commodity prices during the period 2005 through 2008. In its final issue of 2009, "Investment Outlook -America in 2010," Business Week presents speculation in the commodity market as one of five "financial fixes" following the recession. Regulators wanting to curb speculation have also issued new guidelines for trading commodity-based derivatives on the major exchanges in the United States.

The Commitments of Trader (COT) data provides the opportunity to examine positions of large speculators and hedgers in the commodity futures market on a weekly basis. Traders in the futures markets might see this as an opportunity to acquire additional information that can help them predict the direction of the underlying market or gain insights into trading strategies. The dissemination of the positions of more informed traders therefore could be useful in explaining past and future price movements in primary futures markets.

This study includes five contracts trading on U.S. Commodity Futures Exchanges. Corn, Natural Gas, Copper, Live Cattle, and Coffee were selected based on data availability and market size. In viewing these futures markets, the study includes both commodities related to agriculture and those related to energy and basic materials. The development in prices over the time span examined is very different across the sample set. Natural Gas, Corn, and Copper futures prices all spiked between 2006 and 2008, while neither Coffee nor Live Cattle had a comparable increase in price. Casual observation suggests that one explanation might be that Coffee and Live Cattle were not exposed to the high level of speculation observed in Natural Gas, Corn, and Copper markets. However, the open interest and trading volume experienced extraordinary growth over the same period for all of these commodities, except for the Copper futures market. 


\section{A BRIEF DESCRIPTION OF THE FIVE COMMODITIES APPEARS BELOW:}

\section{Corn (Chicago Board of Trade, CBOT)}

The futures contract for corn at CBOT is set at 5,000 bushels per contract, with the specification that delivery be graded \#2 Yellow. This particular grade establishes a minimum bushel weight and maximum limits on damaged and broken kernels. Corn trades in March, May, July, September, and December. The speculative limit set by the CFTC for corn was 22,000 contracts for all months. By comparison, the average daily volume for all corn contracts over the last three years was approximately 270,000 contracts.

\section{Natural Gas (New York Mercantile Exchange, NYMEX)}

This contract specifies delivery at the Henri Hub in Louisiana and a contract size of 10,000 million British thermal units (mmBtu). Monthly contracts are available 12 years in advance, although nearly all open interest is concentrated over the first two years. The speculative limit for Natural Gas is set at 12,000 contracts, as compared to an average of 154,000 contracts traded daily in the last three years.

\section{Copper-Grade \#1 (Commodity Exchange Inc., COMEX)}

The contract size for copper is set at 25,000 pounds per contract. Copper contracts are available for every calendar month, 23 months in advance. Copper deliveries must be Grade 1 Electrolytic Copper Cathodes (full plate or cut) and conform to minimum purity levels. The speculative limit of copper is 5,000 contracts and average daily volume over the last three years in the sample is approximately 20,000 contracts.

\section{Live Cattle (Chicago Mercantile Exchange, CME)}

Live Cattle futures have a size of 40,000 pounds per contract. The product description is 55 percent Choice, 45 percent Select, Yield Grade 3 live steers. Live Cattle futures are delivered every year in February, April, June, August, October, and December. CBOT sets the limit at trading 5,400 Live Cattle futures in any contract month. By contrast, the daily number of contracts traded over the last three years in the sample averaged approximately 36,000 .

\section{Coffee "C" (Intercontinental Exchange, ICE)}

The contract size for coffee is 37,000 pounds per contract. Physical delivery requires Arabica beans in the months of March, May, July, September, and December contracts. The Exchange sets a limit of 5,000 contracts. The average daily volume of coffee contracts was approximately 15,000 through the sample period.

The present study seeks to add to the body of literature on COT data, trading strategies, and the role of speculation on futures prices. It is widely known that individuals and automated algorithms use COT data in the formulation of trading strategies and signals. Floyd Upperman points out in Commitments of Traders (p. 2) that "Indicators derived from (the COT data) can provide traders with a unique perspective that is unobtainable through traditional price-derived methods." Although the extent to which speculation in the futures markets causes prices to diverge from fundamental values will remain unsettled, the immediate analysis will help the discussion by considering the possibility of predictable price movements caused by changes in the positions of major speculators, hedgers, and swap dealers.

\section{CFTC and the Large Reporting System}

The Commodity Futures Trading Commission (CFTC) was created by Congress in 1974 as an independent agency of the federal government to administer the Commodity Exchange Act (CEA). Prior to the establishment of the CFTC, the CEA was administered by the U.S. Department of Agriculture. The role of the CFTC includes exclusive federal jurisdiction over commodities futures and futures options markets in the United States. One of the commission's primary functions is to protect the market from manipulation, abusive trade practices, and fraud. The CFTC also has regulatory oversight of futures exchanges, futures clearinghouses, and other self-regulatory exchanges such as NFA. 


\section{Large Reporting System}

The base for CFTC's surveillance program is the large-trader reporting system. The reporter system collects position-level data from large traders who own or control a relatively large position in a U.S. futures market that is greater than a minimum level set by the CFTC. The level at which a trader has to report to the CFTC obviously differs across commodities. The data is released periodically and compiled into reports that are used to monitor the largest positions of the largest players across a variety of futures markets. The Commitments of Traders (COT) reports date back to 1924, a time when the U.S. Department of Agriculture's Grain Futures Administration published its first comprehensive annual report of hedging and speculation in regulated futures markets. The reports have become more frequent over time and since 2000, reports have been released weekly on the CFTC website.

In the original report, the trader categories were divided into three groups:

- Commercial: Simply, if the trader uses futures contracts in that particular commodity for hedging, the trader falls under the commercial category. A "hedger" is further defined by CFTC:

- $\quad$ Non-commercial: Engages in speculation and not in hedging.

- Non-reporting: Non-reportable positions are total open interest, excluding that part of the open interest reported to CFTC. A trader in this category may thus engage in hedging or speculating activities. This group is frequently referred to as the "small speculator" category.

The data for the report is collected every Tuesday and released on the following Friday at 3:30 p.m. Standard Eastern Time.

\section{Disaggregated Commitment of Trader Data}

The disaggregated data was first available to the public on October 20,2009. Therefore, a very limited number of papers have used the dataset. The data covers a total of 21 commodities over the last three-and-a-half years. The disaggregated Commitments of Traders is a more detailed breakdown of the categories of large traders. The "old" classification in the aggregated reports includes only a commercial and a non-commercial category. The disaggregated report expands this classification, dividing traders into swap dealers, producers, and money managers. In the aggregate report, the commercial category included swap dealers. Technically, swap dealers are hedging, since they are hedging with swaps through the futures market, but disaggregation makes a clearer distinction between the main classifications of traders. Before starting on the analysis of the different groups of traders, a brief explanation of each category in the recently released data is in order:

- $\quad$ Producer/Merchant/Processor/User: Under this category are mainly entities that produce, process, pack, or handle a physical commodity, and use the futures market to hedge against risk.

- $\quad$ Swap Dealer: This entity mainly deals in swap transactions as a form of hedging risks. The swap dealer's counterparts can be speculative traders in hedge funds or traditional commercial clients that manage risk arising from their dealings in physical commodities.

- $\quad$ Money Manager: Money managers engage in managing and conducting organized futures trading on behalf of clients where positions are larger than the reportable limit set by the CFTC. In other words, this group consists of a category that may be termed "large speculators."

- $\quad$ Non-Reportable: The "non-reportable" category is similar to the non-reportable category for the aggregate data; i.e., open interest with the exclusion of that portion reported to the CFTC.

\section{Literature Review}

A good deal of research has been devoted to the relationship between COT data and futures prices for various commodity futures, with most studies seeking evidence that high levels of speculation in different markets can cause prices of certain commodities to rise or fall to unsustainable or destabilizing levels. Although speculation in the futures market has been sharply criticized, especially after the spike in commodities prices in 2005-2008, there is little evidence supporting the ability of any category of traders to move the market in this period. Academics seem to have reached mixed conclusions as to whether the COT data provides any additional information for the traders. 
Hartzmark (1991) looks at the performance of individual futures traders, using unique end-of-the day Commitments of Traders data from CFTC to investigate and analyze the forecasting abilities of over 2,000 individual traders. Hartzmark's methods, as applied to several agricultural and financial futures markets, reveal that the returns to traders of futures are randomly generated. In other words, the article argues that the high positive returns of individual futures traders are determined by luck, as opposed to forecast ability. The study notes, however, that commercial traders show slightly better forecasting abilities than non-commercial traders, and relates this to the fact that the commercial category has access to the most timely data that might prove advantageous in predicting returns. Several articles also make the point that all the studies up until 1991 conclude that the small traders are the big losers and the large traders are the big winners (Stewart, 1949; Houthakker, 1957; Rockwell, 1964, 1977; Hartzmark, 1984, 1987). Leuthold as well as Garcia and Lu (1994) look at relatively similar Commitments of Trader data for trying to predict prices in the Frozen Pork Bellies Futures Market a few years later. This study, however, mainly looks at the speculators' (non-commercial) returns. The authors had access to daily Commitments of Trader data from CFTC, and had 450,000 daily trading observations for 3,171 traders between 1982 and 1990. In this way, the researchers acquired a very detailed picture of what was occurring on a day-to-day basis, and did not have to work with the weekly public data. The study interestingly concludes that large reporting traders generate significant profits and that the distribution over time is non-random, compared to Hartzmark's finding that the return distribution overall was random. The paper also posits that "a subset of large elite traders possesses significant forecasting ability, indicating that they not only are able to consistently anticipate the direction of price changes but are also on the right side of the market when large price changes occur."

Another study, by Ederington and Lee (2002), investigates the 223 largest traders in the heating oil futures market, and questions whether the "commercial" group in the COT report can be classified as hedgers. The authors obtained access to the daily positions from the Commitments of Traders data between 1993 and 1997 and were able to break the group down into 11 subcategories, including refiners and commercial banks (for commercials/hedgers) and floor traders and energy traders (for non-commercial/speculators). The study finds that the traders' approaches are significantly different, depending upon whether they take long or short positions. An additional finding is that, while the large trader non-commercial category seems to comprise speculators, many traders in the commercial group seem to be speculating as well. For example, both refiners and commercial and investment banks (classified as commercials in the Heating Oil futures market) appear to engage in speculation.

Sanders, Irwin, and Mirrin (2008) is one of the papers using the public Commitments of Traders data to determine whether large traders who report positions to CFTC can forecast price or returns. The authors investigate agricultural commodities, including Corn and Live Cattle, but find little evidence that the traders' positions from the COT data are useful for forecasting market return. Weak evidence is found that commercial (hedgers') positions lead returns in a few specific markets. However, the authors find that positions follow returns, and that especially the non-reporting category consists of "trend followers." These findings are supported by other research.

For the energy futures market, a study by Sanders, Boris, and Manfredo (2004) addresses the same topic, looking at the Commitments of Traders data's ability to forecast returns after the release of the data. The authors examine the COT data for commodities such as crude oil, unleaded gasoline, heating oil, and natural gas futures contracts between 1992 and 1999. For the analysis, they use Granger causality tests for a linear regression to test causal relationships. The results are similar in agriculture commodities, in that price changes cause the different categories to change their positions. According to the study, the non-commercial categories increase their positions in a rising market, while commercials decrease their positions in a decreasing market. The study does not find any evidence that traders' PNL positions contain any general predictive information about market returns. The PNL position is the net position for the category divided by the sum of the short and long.

Several studies have analyzed commodities using price return and COT data. Wang (2003) surveys a total of 15 futures markets in the United States, including not only commodity futures, but also currency and S\&P 500 futures. The paper examines performance for the commercial and non-commercial categories in these markets, as well as the determinants of trading decisions. Wang (2003) supports other research which has found that commercials tend to trade against the market, while non-commercials tend to trade with the market. However, Wang's study found that over intervals from 1 to 12 weeks, non-commercial traders' positions forecast price continuations and commercial traders forecast price reversals. The paper also uses the findings of negative 
correlation between performance of speculators and hedgers as evidence of hedging pressure ${ }^{1}$ existing in the futures market. In addition, the study finds that speculators are superior in timing the trading.

A study by Gurrib (2007) uses the Commitments of Traders data to examine how different trading categories react to major economic events in the 1990s. These events include the Asian crisis in 1997 and the Russian bond crisis about a year later. Gurrib (2007) covers 29 U.S. futures markets without going into detail about each market and concludes that informed players in the commodities markets were hardly affected by these events. The relationship between risk and return was stable over the period of the study.

Gurrib's second topic focused on whether the speculative level of various commodity futures could affect prices. In agricultural commodities, Peck (1981) observes the influence of speculators on the futures market for Wheat, Corn, and Soy Beans between 1964 and 1977. The paper uses Working's Speculative Index, introduced later in this paper, to investigate the speculative level in these commodities futures markets. Peck considers the significant growth in the agricultural futures markets, a phenomenon comparable to many commodity futures markets today. His research shows that speculation has declined significantly in the Corn and Soy Bean markets through this period. It is noteworthy that later in the same decade, the Soy Bean futures market was the one to experience extensive manipulation from the Italian firm Ferruzzi ${ }^{2}$ (at that time classified as a hedger).

Sanders, Irwin, and Mirrin (2008) examine the changes in the different categories over time for several agricultural commodities, but does not go into testing relationships between price changes and changes in holdings by these categories. However, the paper is nevertheless interesting because it provides research from six decades measuring Working's Speculative Index, which can be compared to the speculative index from the same commodity today. The paper also looks at the two other reports that CFTC provides for evaluating the level of speculation in the market. One of these, the Commodity Index Traders Report (CIT), breaks down the index traders for 12 agricultural markets. The second, the Bank Participation in Futures Market Report (BP), contains the positions that commercial banks hold in futures markets with at least five banks in open positions. At the end of the paper, the authors note that the last time the commodity markets went through a structural change, in the mid-1970s, the speculators were also blamed for price increases. Chiarella and Röthig (2007) is another relatively recent article concerning speculation in various futures markets. The paper analyzes nonlinear speculation in the commodity futures market for Cattle, Corn, and Hog futures and concludes by rejecting linearity for all markets in the study.

The only article using the disaggregated data to focus on the net positions of different categories is by Hillary Till at the EDHEC-Risk Institute in France. The study looks at Working's Speculative Index for the disaggregated data in the Crude Oil futures market. By simply graphing the speculative index for market participants in the Crude Oil futures market, Till reaches the conclusion that the level of speculation in the oil futures market is not "excessive."

\section{DATA AND METHODS}

This paper uses two sets of data for the analysis. One set of data comes from the Weekly COT (Commitments of Traders) Report, containing weekly observations on futures from 1995-2009 (a total of 778 observations). The main part of the paper uses data from the more detailed Disaggregated Commitments of Traders Report (Disaggregated COT), which was published by the CFTC in the fall of 2009. The observations are also weekly, starting with June 13 in 2006, and conducted to the end of 2009 (187 observations).

This paper uses Holbrook Working's Speculative Index. Working was one of the pioneers in research on the futures markets and is quoted as "the great theorist of futures markets." 3 The index was based on Commitments

\footnotetext{
1 "To transfer nonmarketable risks, hedgers are required to pay a significant premium to speculators for risk-bearing services, which is usually termed the "hedging pressure effect." (Wang, 2003)

${ }^{2}$ The manipulation scandal by Ferruzzi resulted in giant lawsuits and fines. See p. 22 in Futures, options, and swaps, Robert W. Kolb, James A. Overdahl, (2007)

${ }^{3}$ See Robert Schiller, ECON 252: Financial Markets (Spring, 2008), Lecture 22, http://oyc.yale.edu/economics/financialmarkets/
}

2013 The Clute Institute 
of Traders data and set to measure the adequacy of speculative positions to balance the hedging positions held by commercial traders. Working's Speculative Index (also called Working's T Index), is calculated as:

$$
\begin{aligned}
& T=1+\frac{S S}{H L+H S} \text { if } H S \geq H L \\
& \text { or } \\
& T=1+\frac{S L}{H L+H S} \text { if } H L \geq H S
\end{aligned}
$$

where: T= Working's Speculative Index, SS = Speculator short, $\mathrm{SL}=$ Speculator long, $\mathrm{HL}=$ Hedger long, and HS = Hedger short

The denominator shows the total open interest from hedge positions. If the amount of short hedging is greater than the amount of long hedging, speculative longs are needed to balance the market and technically, speculative shorts are not required by hedgers. Any surplus of speculative short positions would need to be balanced by additional speculative long positions. The Speculative Index measures excess speculative positions beyond what are technically required to balance commercial needs. This excess is measured relative to commercial open interest. Sanders, Irwin, and Mirrin (2008) are among the articles that examine the Speculative Index. The paper also compares current levels of the index for a few agricultural commodities with former research using this Speculative Index. The study found that "after adjusting speculative indices for index fund positions, values are within the historical ranges reported in prior research" dating back to 1960. Over time, these values have ranged between 1.15 and 1.65. In this paper, the speculative index is calculated for a total of 10 relatively large commodity futures markets between 1995 and 2009 (graph 2.1), including the five commodities discussed.

Several papers (e.g., Leuthold, 1983; Sanders, 2008) have noted the obvious problem that one does not know how to specify non-reporting traders when calculating the Speculative Index. This could be significant and should be kept in mind when studying this index. For the commodities in this analysis, Soy Beans, Live Cattle, and Corn have the highest percentage of non-reporting traders relative to total open interest (non-commercial corn short around 25 percent of the total open interest).

To determine the correlations between the different categories and to perform the causality tests, the percentage each category is long was calculated simply by:

$$
\text { Percentage long } \text { category }=\frac{L_{c}}{L_{c}+S_{c}}
$$

Where $L_{c}=$ Long in trader category and $S_{c}=$ Short in trader category

Augmented Dickey-Fuller (ADF) and KPSS tests were applied to the aggregated and disaggregated COT time series and associated commodity prices. Both the ADF test and the KPSS determine whether there is a unit root present in an autoregressive model. Results from these tests are shown in table 5.1 in the Appendix.

The disaggregated data were evaluated to see whether changes in holdings among certain categories of traders can cause prices to change and whether price changes lead certain categories of traders to change their positions. A linear vector autoregression (VAR) model was estimated with a number of lags to minimize AIC ${ }^{4}$. A Granger test was then conducted for five commodities. Granger (1969) developed this test to determine whether past terms contain information that will be useful in forecasting a term that occurs later in a series.

\footnotetext{
${ }^{4}$ Akaike's Information Criterion (AIC) was proposed by Akaike $(1969,1973,1974)$ and is used for measuring the goodness of fit for a particular model by balancing the error of the fit against the number of parameters in the model. See pp. 53, Shumway, Stoffer (2006).
} 
Davidson and MacKinnon (1993) give one explanation of Granger causality or, technically, Granger noncausality. It is made in a context of models $\mathrm{M}$ that contain DGP's ${ }^{5}$ capable of generating two sets of variables, $\mathrm{Y}_{\mathrm{t}}$ and $\mathrm{X}_{\mathrm{t}}$. In the definition, $\mathrm{Y}^{\mathrm{t}-1}$ and $\mathrm{X}^{\mathrm{t}-1}$ denote the rows of the matrices $\mathrm{Y}$ and $\mathrm{X}$, respectively, prior to the $\mathrm{t}^{\text {th. }}$. Thus $\Omega_{\mathrm{t}}$ consists of $\mathrm{Y}^{\mathrm{t}-1}$ and $\mathrm{X}^{\mathrm{t}-1}$ :

Definition: The variables $\mathrm{Y}^{\mathrm{t}-1}$ do not Granger cause the $\mathrm{X}_{\mathrm{t}}$ in a model $\mathrm{M}$ containing DGPs characterized by contributions if and only if:

$l_{t}^{x}\left(X_{t} \mid \Omega_{t}\right)=l_{t}^{x}\left(X_{t} \mid \Omega^{t-1}\right)$

In other words, $Y^{t-1}$ does not Granger cause $X_{t}$ if the distribution of $X_{t}$ conditional on the past of both $X_{t}$ and $Y_{t}$ is the same as that conditional on the past of $X_{t}$ alone. This can be expressed by stating that the past of $Y_{t}$ contains no information about $X_{t}$ that is not already contained in the prior $X_{t}$. For a VAR model, as in this paper, the model can be used to test the null hypothesis that one variable does not Granger cause another variable. This hypothesis is tested using an F-test. For the Granger test, this paper tests the relationships from week to week (Tuesday to Tuesday), and from Friday, when the COT data is released, to the end of next three trading days (i.e., Monday, Tuesday, and Wednesday).

Further, these relationships will be tested as follows:

For week-to-week:

$\Delta$ Net positions $_{\text {category }} \underset{\text { Grangercause }}{\longrightarrow} \Delta$ Price $_{\text {commodity }}$

$\Delta$ Price $_{\text {com modity }} \underset{\text { Grangercause }}{\longrightarrow} \Delta$ Net positions category

For COT-release on the next three trading days:

$\Delta \%$ long position category $_{\text {Grangercause }} \Delta \operatorname{Price}_{i}$

$\Delta$ Price $_{i} \underset{\text { Grangercause }}{\longrightarrow} \Delta \%$ long position category

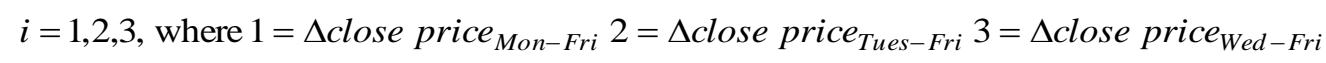

\section{INITIAL ANALYSIS OF COT DATA AND THE FUTURES MARKETS}

\section{Working's Speculative Index}

The Speculative Index was created for the five commodities evaluated by this study. In addition, the Speculative Index was developed for four other highly traded commodities that were included in the calculation. The Speculative Index for all the commodities is shown in graph 2.1. Lumber was originally included in the graph, but since the market size is very small relative to the other commodities, it was dropped from further analysis. The graph is relatively noisy, but one can see which commodities have operated consistently in the top levels of the Speculative Index over recent years. Natural Gas and Live Cattle have one of the highest values on this graph. The Speculative Index for Natural Gas peaked in the beginning of 2008, while the Live Cattle futures seem to be consistently higher on the index than most other commodities. However, the commodity experienced a peak in the index level in 1999 and at the end of the period under consideration (late 2009). When looking into the COT data set for Natural Gas, it

${ }^{5}$ DGP = Data Generating Process. See Davidson and MacKinnon (1993). 
seems that the peak in the index in 2008 was caused by a high short position among speculators relative to the hedgers. At the time, a little less than 80 percent of the market positions among the speculators were short positions. For Live Cattle, the 1999 peak was due to most speculators being long relative to themselves from a temporal setting and to the commercials in a contemporary setting. The recent increase in the index simply reflects a relatively high level of non-commercial traders active in the Live Cattle market.

Table 2.1 Workings Speculative T, Ranges in Index Values 1995 -2009 for Aggregate Commitments of Traders Data

\begin{tabular}{lccccccccc}
\hline $\begin{array}{l}\text { Futures } \\
\text { market }\end{array}$ & Sugar & $\begin{array}{c}\text { Soy } \\
\text { beans }\end{array}$ & $\begin{array}{c}\text { Natural } \\
\text { gas }\end{array}$ & $\begin{array}{c}\text { Live } \\
\text { Cattle }\end{array}$ & Coffee & Copper & Gold & $\begin{array}{c}\text { Crude } \\
\text { Oil }\end{array}$ & Corn \\
\hline & $(1.01-$ & $(1.02-$ & $(1.00-$ & $(1.03-$ & $(1.01-$ & $(1.01-$ & $(1.01-$ & $(1.00-$ & $(1.01-$ \\
Ranges & $1.33)$ & $1.31)$ & $1.41)$ & $1.43)$ & $1.34)$ & $1.41)$ & $1.40)$ & $1.18)$ & $1.28)$ \\
\hline
\end{tabular}

Note: Range of Values for Working Speculative T in the data set this paper is looking at (1995-2009)

In the review of the study by Sanders, Irwin, and Merrin (2008) noted earlier in this paper, it is possible to compare the historical values for the speculative index with these values over the last 15 years. The authors provide values for several agricultural futures markets through six decades for some commodities. Among these markets are Corn, Soy Beans, and Live Cattle. Upon comparing the range from Table 2.1, none of these commodities appear to be far outside the historical averages. Rather, the levels today seem to be lower than averages that prevailed in the past.

\section{Trends in Market Activity}

Consistent with general observations on the broad futures markets, commodity futures markets have seen a significant growth during the last 15 years. The volume and open interest for all the commodities considered in the present study have experienced this consistent trend. Graphs 1.1-1.5 illustrate the increase in volume, open interest, price, and speculative index for the five commodities. The first trend that appears obvious across all five future markets is the surge in volume and open interest for the commodities between early 2005 and the beginning of 2007. In Corn, for example, both open interest and volume grew by around 250 percent in this period, and other agricultural commodities such as Coffee showed the same trend. Live Cattle also showed increasing volume and open interest in the same period, but this continued in 2009, even though the Live Cattle price has decreased over recent years. For Natural Gas and Copper there has also been a significant growth in both open interest and volume in 2009.

\section{Position Changes in Trader Categories}

The percentage long per category for each commodity futures market is shown in Figures 3.1-3.5 in the appendix. Disaggregated data available from June 2006 are used for the graphs and Table 3.2 below, which shows the summary statistics for these data.

The results show that all five futures markets have significant differences in the breakdown of different trader categories. In markets such as the Live Cattle and Coffee futures markets, the producers are consistently short over the period this data covers. In the same markets, it appears that swap dealers are consistently long. Money Managers appear to be the category that changes positions the most through the time period. Money Managers have been both very short and very long over this period in the Coffee and Copper futures market. For the noncommercial category, they are acting more like the Money Manager category in the Coffee and Copper markets, where the category has a relatively wide range of percentage long. For the rest of the markets, the non-commercials appear to be performing more like the producer category. 
Table 3.2 Summary Statistics for the Percentage which each Trader Category is Long in the Respective Futures Market

\begin{tabular}{|c|c|c|c|c|c|c|c|c|c|c|c|c|c|c|c|}
\hline & \multicolumn{3}{|c|}{ Corn } & \multicolumn{3}{|c|}{ Natural Gas } & \multicolumn{3}{|c|}{ Live Cattle } & \multicolumn{3}{|c|}{ Copper } & \multicolumn{3}{|c|}{ Coffee } \\
\hline & Mean & S.D. & Range & Mean & S.D. & Range & Mean & S.D. & Range & Mean & S.D. & Range & Mean & S.D. & Range \\
\hline $\begin{array}{l}\% \\
\text { long } \\
\text { prod }\end{array}$ & 32.4 & 5.0 & $\begin{array}{c}(20.8- \\
45.0)\end{array}$ & 50.0 & 4.9 & $\begin{array}{c}(43.2- \\
61.5)\end{array}$ & 20.6 & 5.1 & $\begin{array}{c}(10.5- \\
32.4)\end{array}$ & 30.2 & 11.6 & $\begin{array}{l}(5.1- \\
49.7)\end{array}$ & 28.7 & 8.3 & $\begin{array}{c}(11.3- \\
45.8)\end{array}$ \\
\hline $\begin{array}{l}\% \\
\text { long } \\
\text { swap }\end{array}$ & 97.1 & 3.3 & $\begin{array}{c}(88.8- \\
100)\end{array}$ & 64.7 & 20.3 & $\begin{array}{c}(30.9- \\
95.2)\end{array}$ & 96.4 & 1.5 & $\begin{array}{l}(91.2- \\
98.4)\end{array}$ & 76.9 & 7.4 & $\begin{array}{c}(57.0- \\
91.3)\end{array}$ & 92.2 & 6.7 & $\begin{array}{c}(77.0- \\
100)\end{array}$ \\
\hline $\begin{array}{l}\% \\
\text { long } \\
\text { MM }\end{array}$ & 78.7 & 13.7 & $\begin{array}{c}(45- \\
98.7)\end{array}$ & 38.5 & 11.4 & $\begin{array}{c}(19.6- \\
65.0)\end{array}$ & 67.7 & 10.6 & $\begin{array}{c}(49.4- \\
89.1)\end{array}$ & 42.2 & 16.8 & $\begin{array}{c}(10.1- \\
73.0)\end{array}$ & 62.4 & 18.9 & $\begin{array}{c}(28.1- \\
90.2)\end{array}$ \\
\hline $\begin{array}{l}\% \\
\text { long } \\
\text { non }\end{array}$ & 38.7 & 3.6 & $\begin{array}{c}(26.8- \\
45.1)\end{array}$ & 65.9 & 2.6 & $\begin{array}{c}(59.0- \\
73.5)\end{array}$ & 30.8 & 3.5 & $\begin{array}{c}(23.1- \\
40.5)\end{array}$ & 47.6 & 4.4 & $\begin{array}{c}(37.1- \\
57.7)\end{array}$ & 58.6 & 5.7 & $\begin{array}{c}(39.8- \\
70.1)\end{array}$ \\
\hline
\end{tabular}

The data is from the Disaggregated Commitments of Traders report starting in June 2006 until the end of 2009.

\section{RESULTS AND ANALYSIS}

\section{Correlations between Variables}

The correlation coefficients from the percentage long per category for each of the five markets are shown in Table 4.1 in the appendix. The results add to the graphs in the last section and reveal how the different categories react relative to each other and relative to the price of the commodity.

For the correlations between the different trader categories and the futures price of the commodity, there are differences between the various commodities. However, in general, the Producer category seems to move against the market (i.e., producers increase their long positions when prices are falling), a result that is consistent with previous research. The results also show that participants within the Money Manager category favor momentumbased strategies, in that they increase their long positions when commodity prices increase. The correlation between these two categories shows a very strong negative relationship between the net positions for the different categories. In other words, speculators often take the opposite side of the producers in trades. This is consistent with a common assumption in theoretical and empirical research. The Swap Dealers' positions in the different markets are more mixed. One might expect this category to exhibit a strong negative correlation with the Money Managers, since these might be the most likely counterparts for the Swap Dealers when trying to hedge the risk. However, for the Corn and Live Cattle futures market, it appears that Producers are the counterparts in the swap trades. Moreover, a very weak correlation between Swap Dealers in Corn and Live Cattle markets is also due to the fact that Swap Dealers are consistently long on these two commodities, which makes a simple correlation coefficient measurement inaccurate. For the Non-commercial and Other reporting traders categories, there is no consistent relationship between how the traders change their net positions relative to price and the other categories. One reason for this could be that these groups are very diverse and contain both traders with speculating objectives and traders with hedging objectives. For non-reporting traders, the results from this simple correlation matrix might indicate that the non-reporting traders act more like the Producers in the way that they increase their net positions as price goes down (with the exception of non-commercial traders in the Corn futures market). In the Live Cattle futures market, it appears that the non-commercial traders change their long positions in the same direction as producers (the correlation between the Non-reporting and the Producer net positions had a high positive correlation), while for the Copper and Coffee futures, the Non-reporting traders tend to take the same direction as the Money Managers. The correlation charts and the summary statistics data from Table 3.2 give the clear impression that the label "small speculators" for the non-reporting category is not always appropriate for all futures commodities. Rather, it appears that the non-commercial group is acting more like large hedgers in some commodities and more like large speculators in other futures markets. However, this could also imply that the Non-reporting category might try to mimic the Producers.

\section{Results from Granger Causality Tests and Interpretations}

The results from the Augmented Dickey-Fuller test and the KPSS test are shown in Table 5.1 in the appendix. Even though many of the level time series seem to be non-stationary, it helps to take the first differences of most of the time series. 
The results of the first Granger causality tests, which show the change in net positions from week-to-week, are in Table 6.1 in the appendix. The analysis of the results from these data yields two conclusions. First, as pointed out in earlier research, there is a tendency among the non-reporting trader category to adjust net position to the changes in price. For all markets but one, the null hypothesis for Granger non-causality could be rejected on a 95 percent confidence interval. When looking at the Coffee futures market, it appears that changes in price Granger cause producers, money managers, and non-reporting traders to change their positions.

The Live Cattle futures market is the only market where it seems that the week-to-week change in net positions may Granger cause a price change. Both the Producers and the Speculators changing their net positions appear to Granger cause this change in price. This is an interesting finding, since it could imply that these categories have strong influence in the Live Cattle futures market. Other articles, such as Chiarella and Röthig (2007), also found the Live Cattle price market to have different characteristics when applying it with price in a linear VAR model. However, the authors in this article go further, to find nonlinearities in changes in holdings on price changes in several futures markets.

The results from the second Granger test (whether changes in percent long in a category can affect the price change from when the data is released and the next three days) are found in Table 7.1. The results suggest that from the VAR model, it is not possible to find many causal relationships between categorical changes in holdings and changes in price during the days following the release of the COT data. There were some significant relationships in these results. For the swap dealers in the Copper market, and for Money Managers in Natural Gas, both have significant values for the day after the release of the COT data. There is also a weak Granger causality between Producers' holdings and price changes in the Coffee futures market on the first day. This might imply that there is some information in the Commitments of Traders data, as suggested by Wang (2003). This study cannot rule out that profitable trading strategies exist. That most of the relationships found are in the "old" commercials category also supports previous research suggesting that the commercial group in the aggregate data has an information advantage over the non-commercial categories.

The values are also significant considering that a change in Swap Dealers' holdings Granger cause the price change in the Corn futures market three days after the release of the COT data. However, since there is no causality between the one- and two-day return and changes in holdings among this category, this finding is very difficult to interpret.

Last, it is important to note that since the disaggregated data covers a significantly shorter time period than the coverage of aggregate Commitments of Trader data, the strength and applicability of the conclusions are diminished. It will be interesting to see whether more time and data could expand upon the results found in the immediate study.

\section{CONCLUSIONS}

This study tests Granger causalities for commodities in different markets that both did and did not experience spikes in futures prices between 2005 and 2008. More specifically, the study observes speculative levels and their predictability from the Commitments of Trader (COT) data. The study finds that there is a tendency to herd in several commodity markets, which is consistent with previous research. It also appears that large traders and hedgers have more influence in certain commodity futures. One example is the Live Cattle market. The study further tests whether the COT data has any predictive power after it is released. Very limited evidence is found that the recent Disaggregated COT data has any predictive power. In some commodities, it seems that changes in Swap Dealers' and Producers' positions can Granger cause the prices to change. However, this is not consistent through the different commodities.

\section{AUTHOR INFORMATION}

Einar M. Often, analyst, Alpha Corporate Finance, Karl Johans gate 27, 0159 Oslo, Norway, Email: emoften@gmail.com 
Craig H. Wisen, Ph.D., associate professor of finance, University of Alaska Fairbanks School of Management, 303 Tanana Lp., 201 Bunnell, Fairbanks, AK 99775, Email: chwisen@alaska.edu (Corresponding author)

\section{REFERENCES}

1. Bryant, H., Bessler, D. A., \& Haigh, M. S. (2006). Causality in futures markets. The Journal of Futures Markets, 26, 1039-1057.

2. Chiarella, C., \& Röthig, R., (2007). Investigating nonlinear speculation in cattle, corn, and hog futures markets using logistic smooth transition regression models. The Journal of Futures Markets, 27(8), 719737.

3. Davidson, R., \& MacKinnon, J. G. (1993). Estimation and inference in econometrics. New York: Oxford University Press.

4. Ederington, L., \& Lee, J. H. (2002). Who trades futures and how: Evidence from the heating oil futures market. The Journal of Business, 75(2), 353-373.

5. CME Group. (2009). Excessive speculation and position limits in energy derivatives markets. Chicago, IL: Author. Retrieved from http://www.cmegroup.com/company/files/PositionLimitsWhitePaper.pdf

6. Financial fixes. (2009, December 28). Bloomberg Businessweek Magazine.

7. Government Archives and Records Administration. (2013). Speculative limits, SEC. Retrieved from http://ecfr.gpoaccess.gov

8. Gurrib, I. (2007). Do large hedgers and speculators react to events? A stability and events analysis. Icfai IUP Journal of Financial Economics, 5(2), 31-41.

9. Hartzmark, M. (1991). Luck and forecast ability: Determinants of trader performance in futures markets. Journal of Business, 64, 49-74.

10. Kilian, L., \& Park, C. (2007). The impact of oil price shocks on the U.S. stock market. International Economic Review, 50(4), 1267-1278.

11. Kolb, R. W., \& Overdahl, J. A., (2007). Futures, options, and swaps. Maldan, MA: Blackwell Publishing.

12. Leuthold, R. M. (1983). Commercial use and speculative measures of the livestock commodity futures markets. Journal of Futures Markets, 3, 113-135.

13. Leuthold, R. M., Garcia, P., \& Lu, R., (1994). The returns and forecasting ability of large traders in the frozen pork bellies futures market. The Journal of Business, 67(3), 459-473.

14. Peck, A. E. (1981). The adequacy of speculation on the wheat, corn, and soybean futures markets. In R. A. Goldberg (Ed.), Research in domestic and international agribusiness management, Vol. 2 (pp. 67-29). Greenwich, CT: JAI Press.

15. Sanders, D. R., Boris, K., \& Manfredo, M. (2004). Hedgers, funds, and small speculators in the energy futures markets: An Analysis of the CFTC's Commitments of Traders Reports. Energy Economics, 26, 425-445.

16. Sanders, D. R., Irwin, S. H., \& Merrin, R. (2007). Smart Money? The forecasting ability of CFTC large traders. Proceedings of the NCCC-134 Conference on Applied Commodity Price Analysis, Forecasting, and Market Risk Management. Chicago, IL. Retrieved from: http://www.farmdoc.uiuc.edu/nccc134

17. Sanders, D. R., Irwin, S. H., \& and Merrin, R. P. (2008). The adequacy of speculation in agricultural futures markets: Too much of a good thing? Marketing and Outlook Research Report, 32(1), 77-94.

18. Shumway, R. H., \& Stoffer, D. S. (2010). Time series analysis and its applications. New York: Springer.

19. Till, H., (2009). Has there been excessive speculation in the U.S. oil futures markets? Nice, France: EDHEC-Risk Institute.

20. U.S. Commodity Futures Trading Commission homepage and Commitments of Traders reports http://www.cftc.org

21. Upperman, F. (2006). Commitments of traders: Strategies for tracking the market and trading profitably. Hoboken, NJ: Wiley.

22. Wang, C. (2003). The behavior and performance of major types of futures traders. Journal of Futures Markets, 23, 1-31.

23. Working, H. (1960). Speculation on hedging markets. Food Research Institute Studies, 1, 185-220. 


\section{APPENDIX}

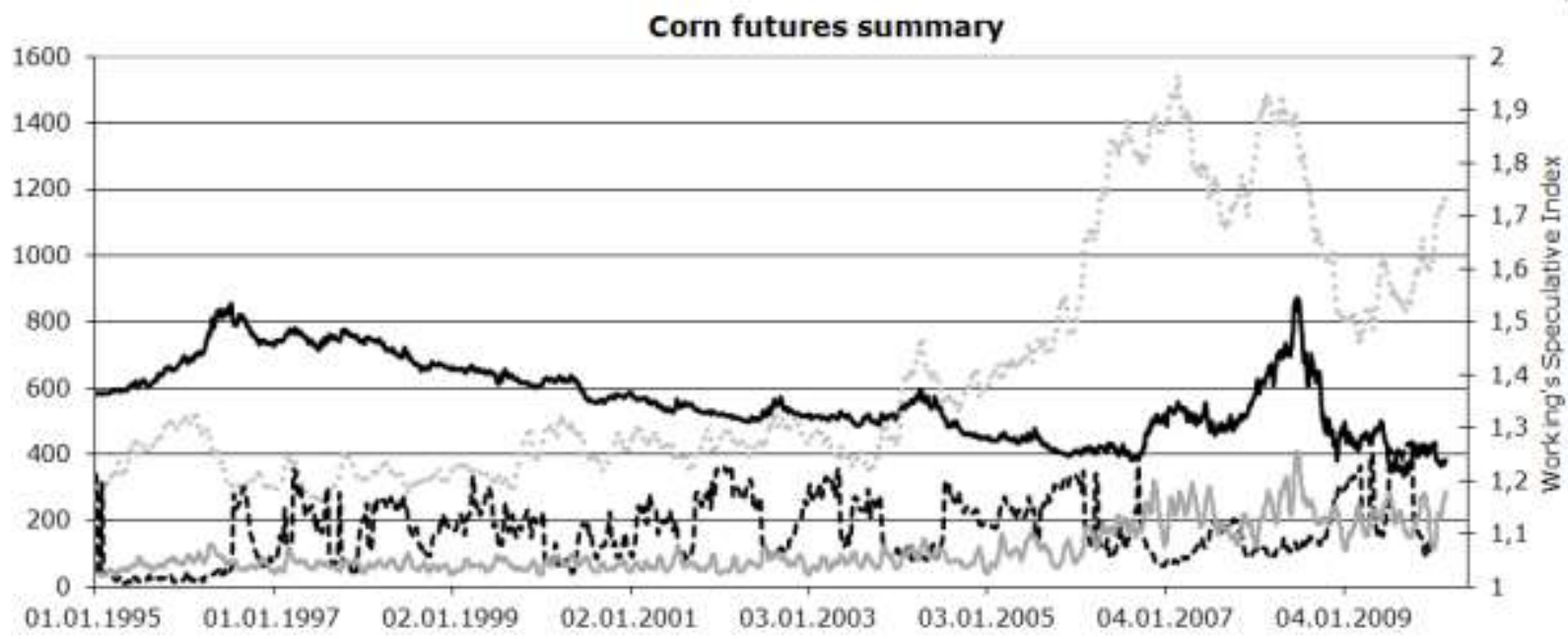

C Corn price $\quad . . . .$. Open Interest (in $\left.000^{\prime}\right) \quad$ -

Figure 1.1 Summary Data for the Corn Futures Prices, Volume, Open Interest, and Working's Speculative Index

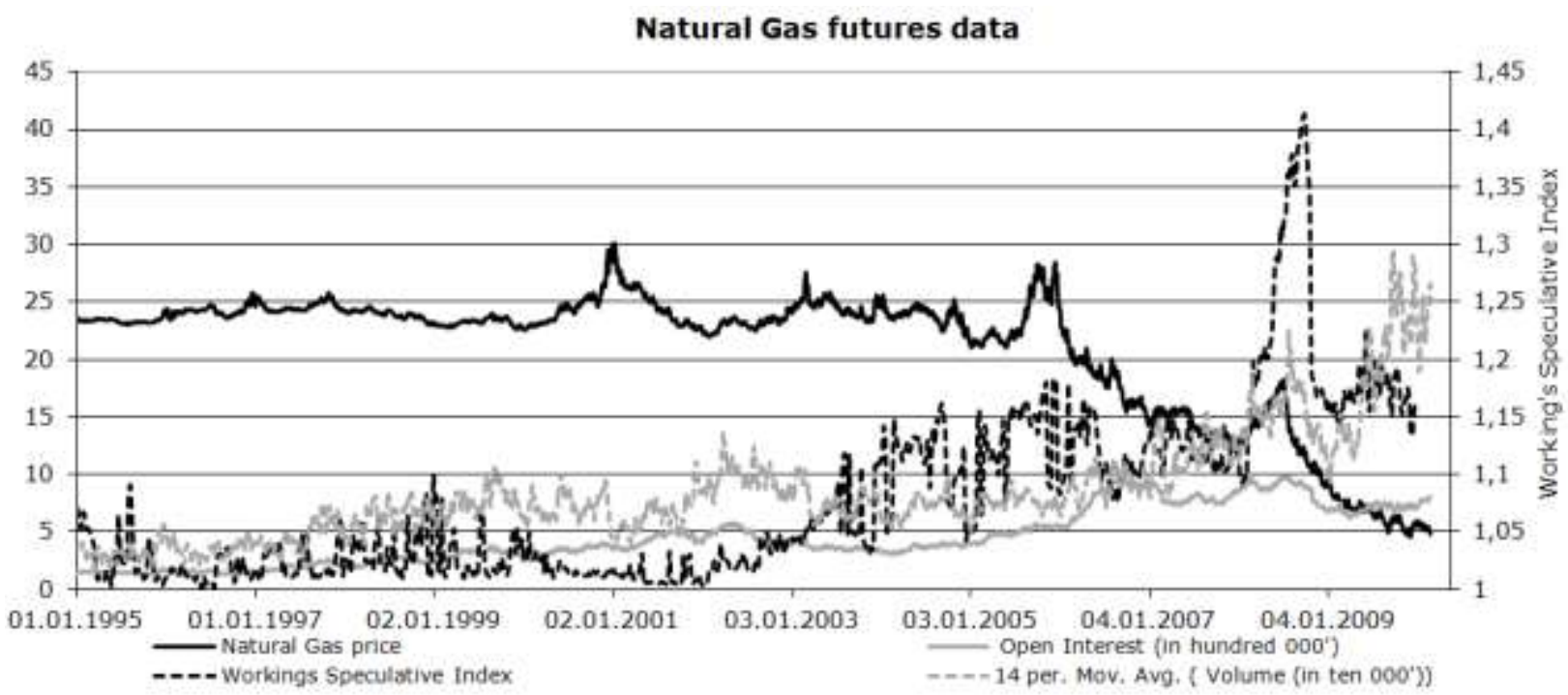

Figure 1.2 Summary Data for the Natural Gas Futures Prices, Volume, Open Interest, and Working's Speculative Index 


\section{Copper futures summary}

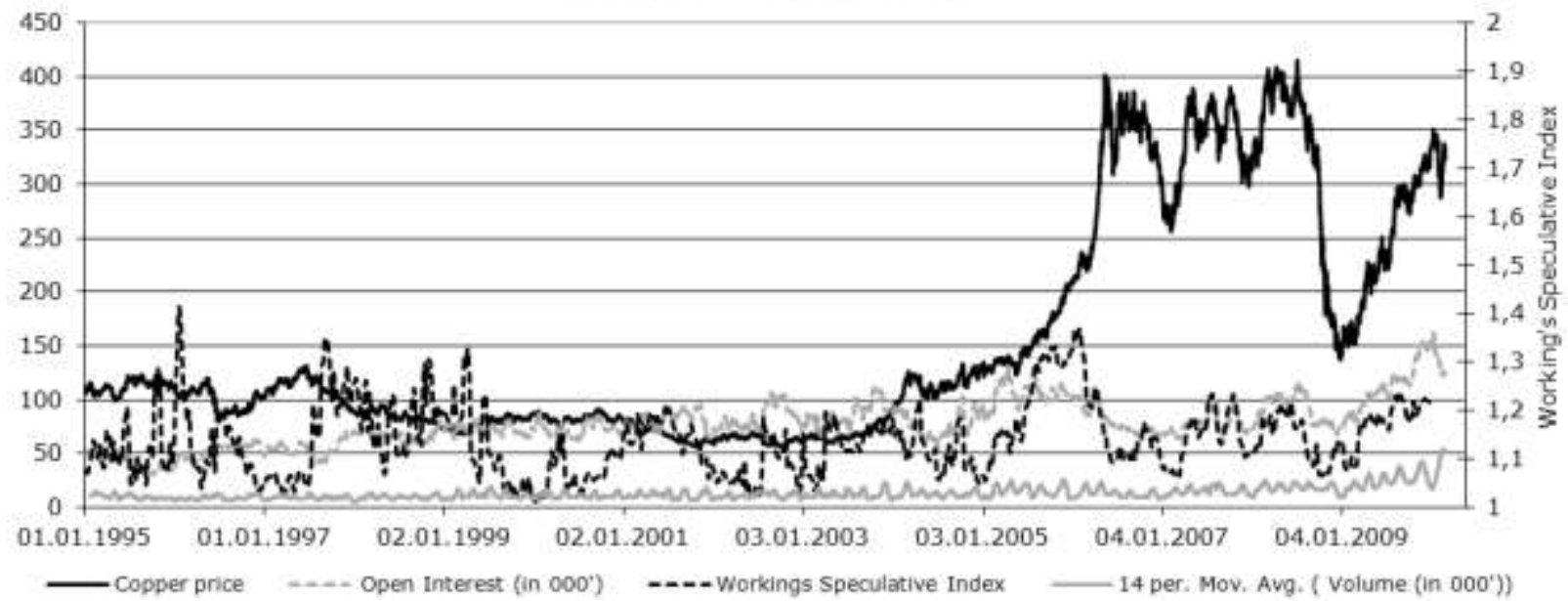

Figure 1.3 Summary Data for the Copper Futures Prices, Volume, Open Interest, and Working's Speculative Index

Live Cattle Futures summary

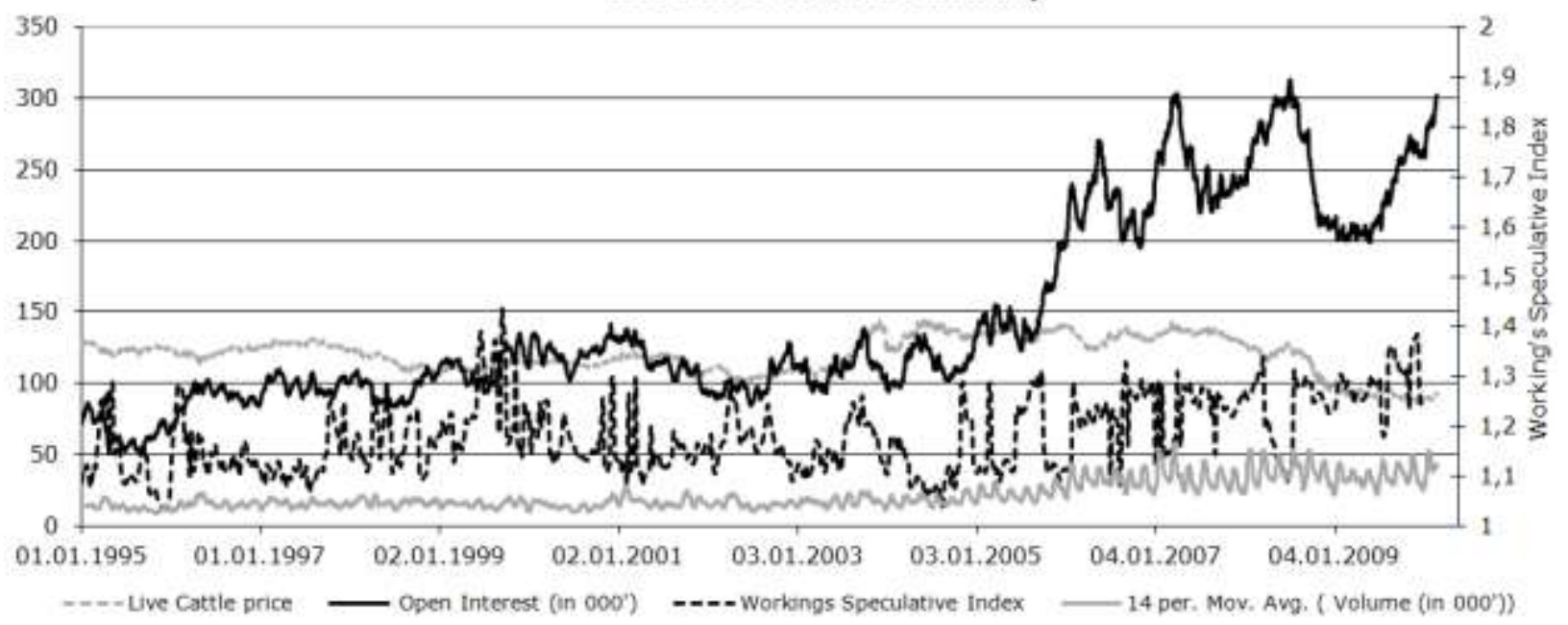

Figure 1.4 Summary Data for the Live Cattle Futures Prices, Volume, Open Interest, and Working's Speculative Index 


\section{Coffee futures summary}

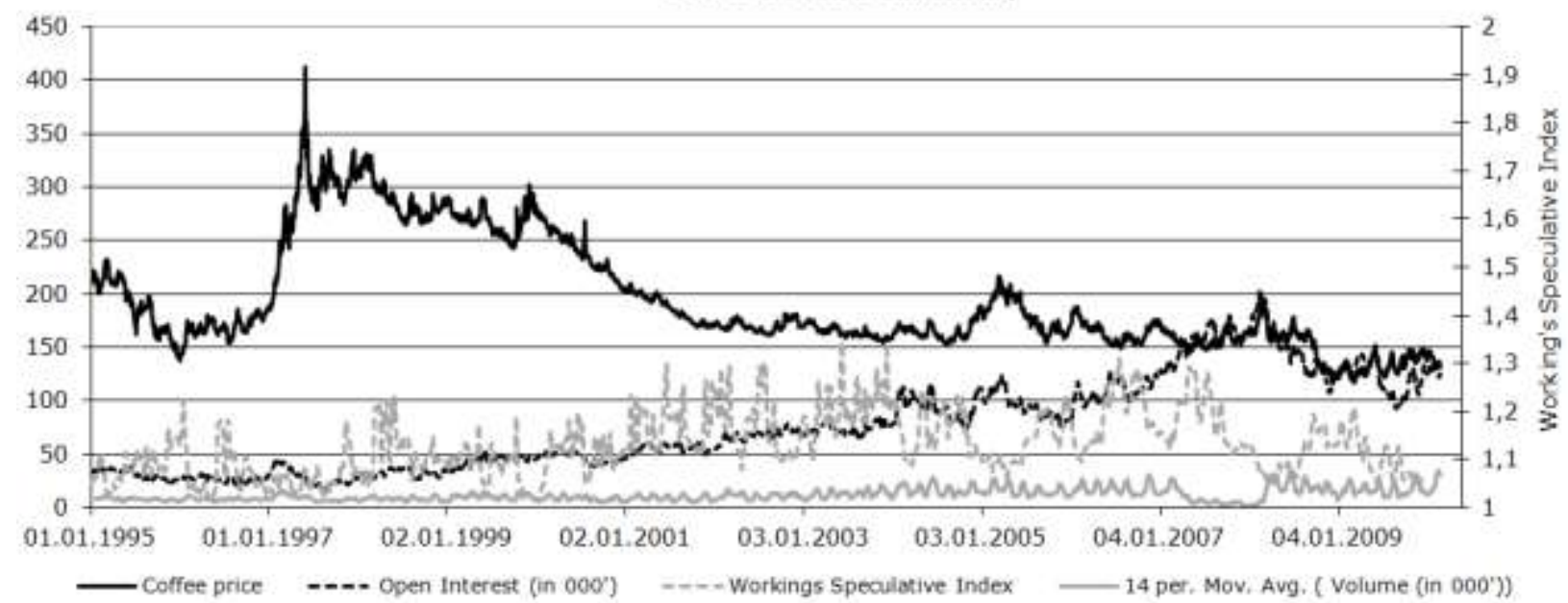

Figure 1.5 Summary Data for the Coffee Futures Prices, Volume, Open Interest, and Working's Speculative Index

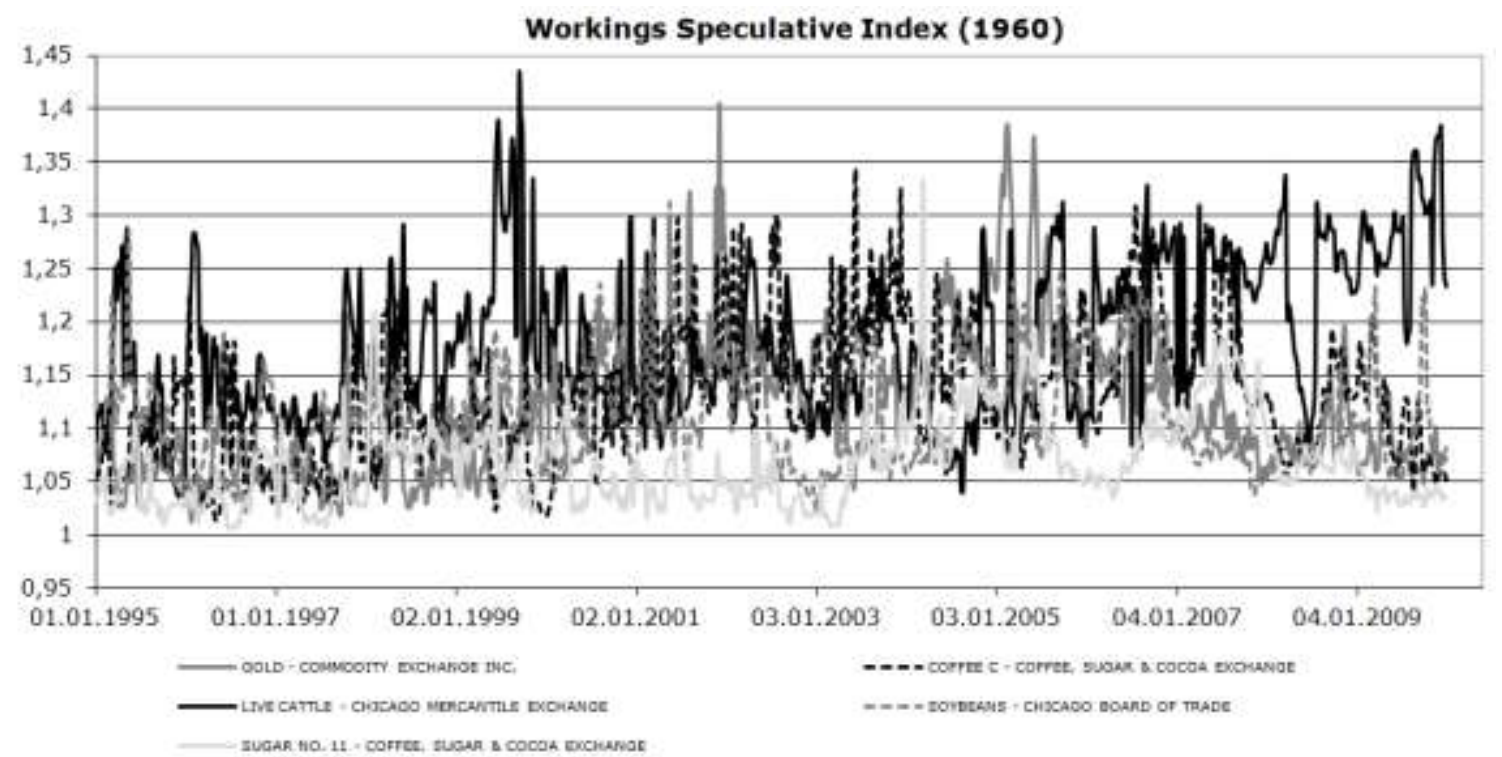

Figure 2.1(a) Working's Speculative Index for 10 Commodities from 1995-2009 


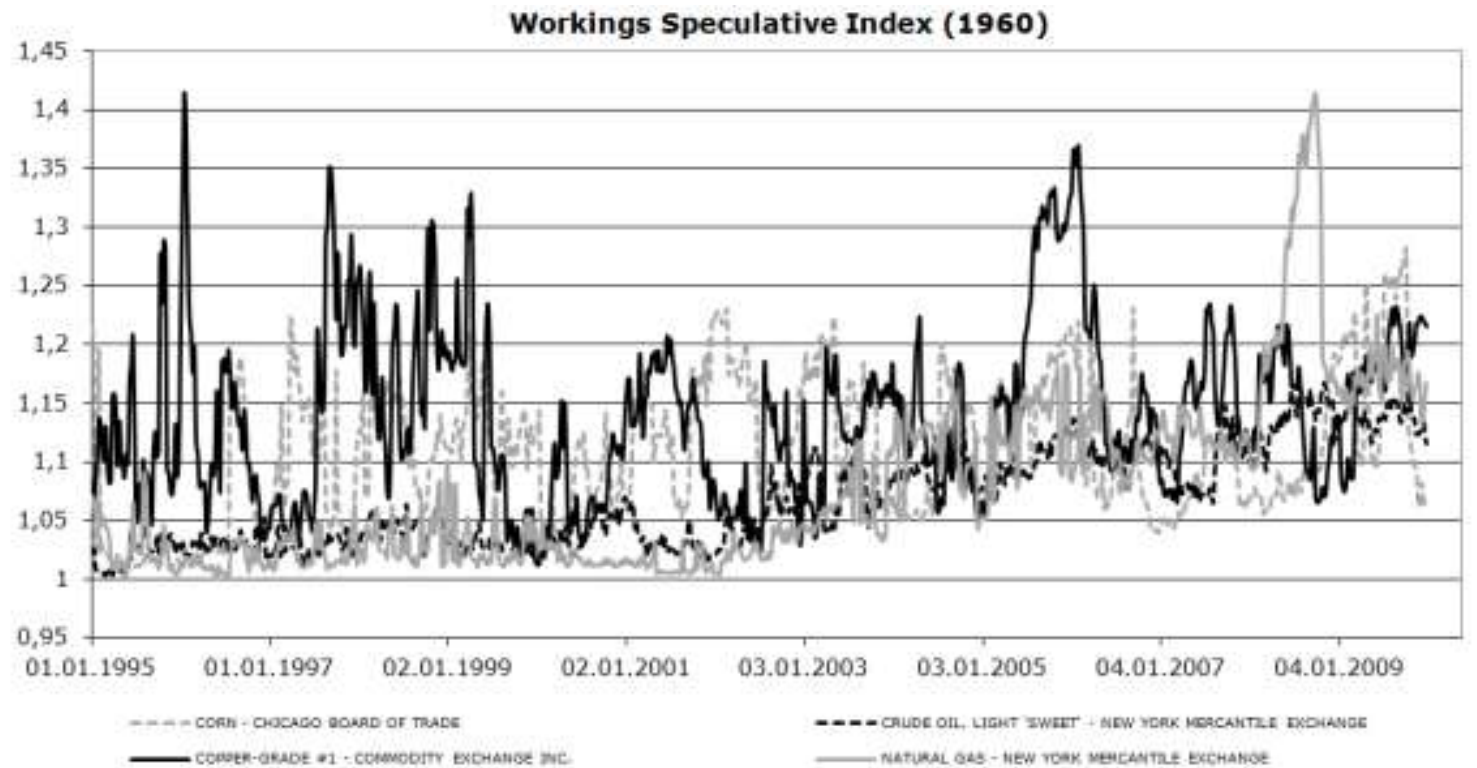

Figure 2.1(b) Working's Speculative Index for 10 Commodities from 1995-2009

\% long to category: Corn futures market

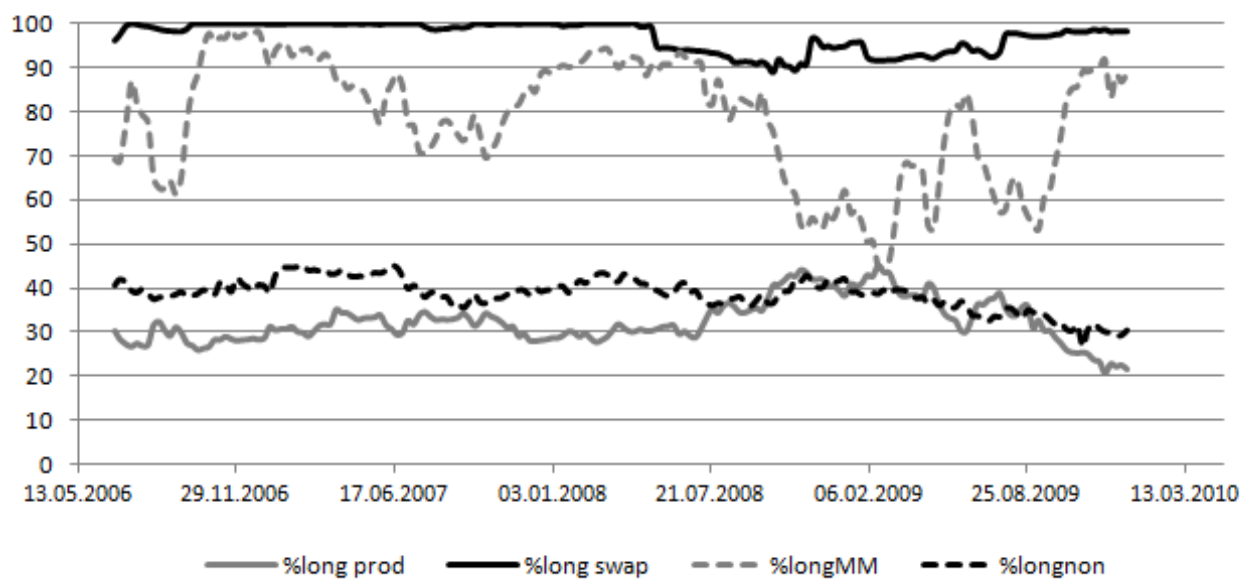

Figure 3.1 Breakdown of the Percentage Long for each Category for the Corn Futures Market 


\section{\% long to category: Natural Gas futures market}

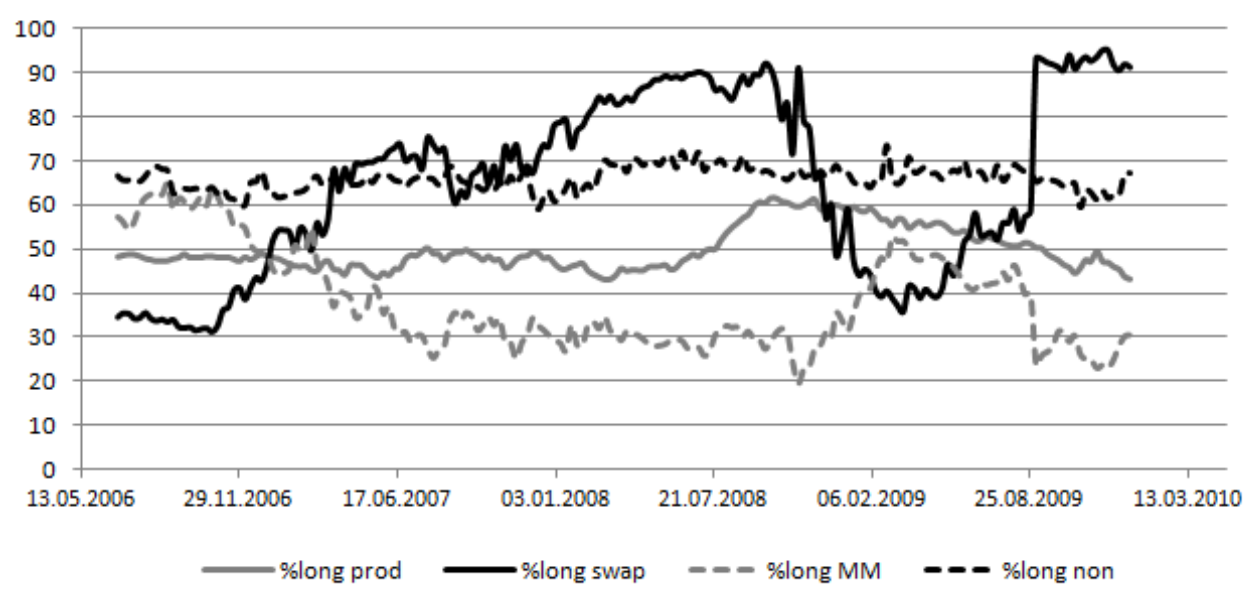

Figure 3.2 Breakdown of the Percentage Long for each Category for the Natural Gas Futures Market

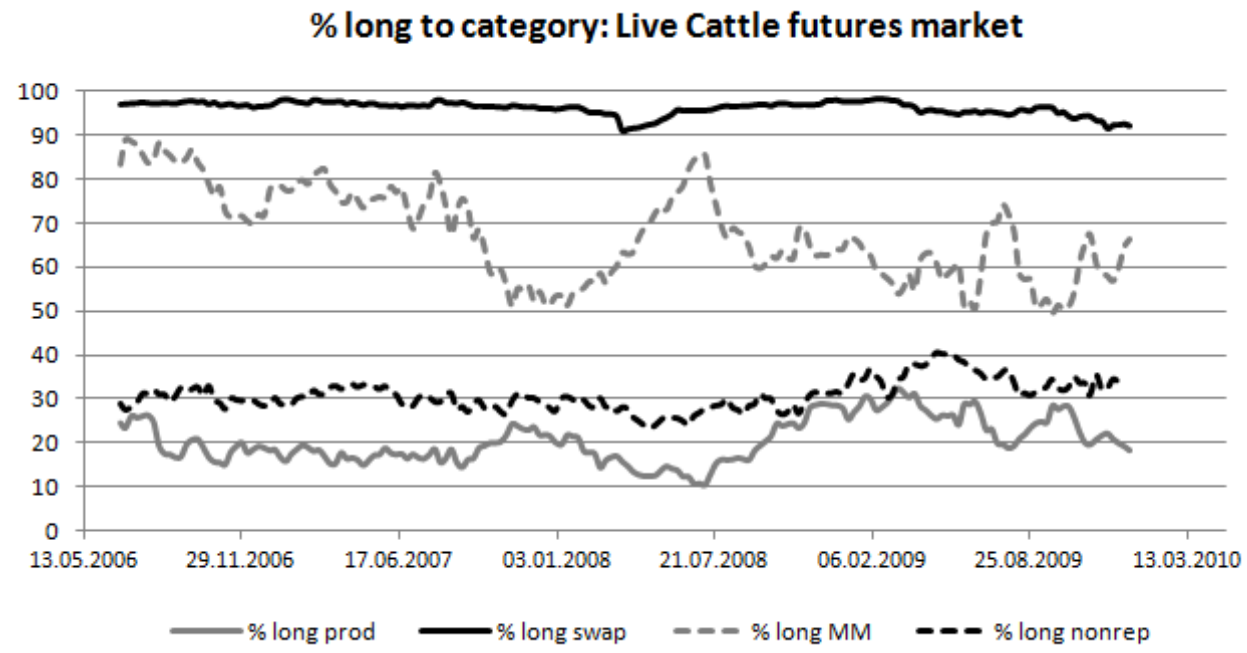

Figure 3.3 Breakdown of the Percentage Long for each Category for the Live Cattle Futures Market 


\section{$\%$ long to category: Copper futures market}

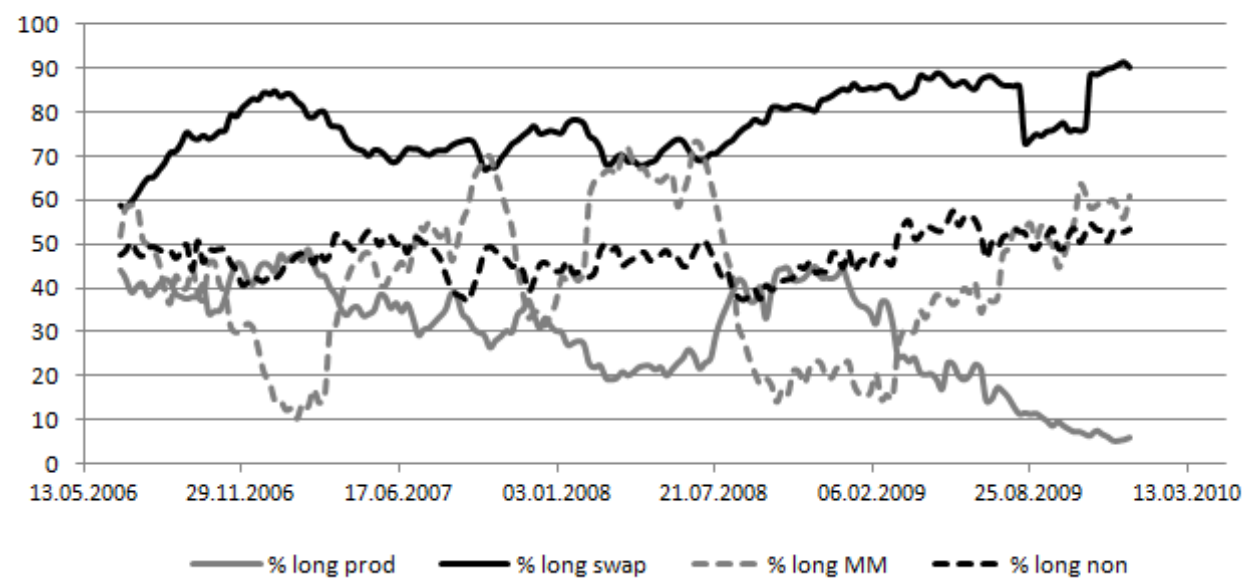

Figure 3.4 Breakdown of the Percentage Long for each Category for the Copper Futures Market

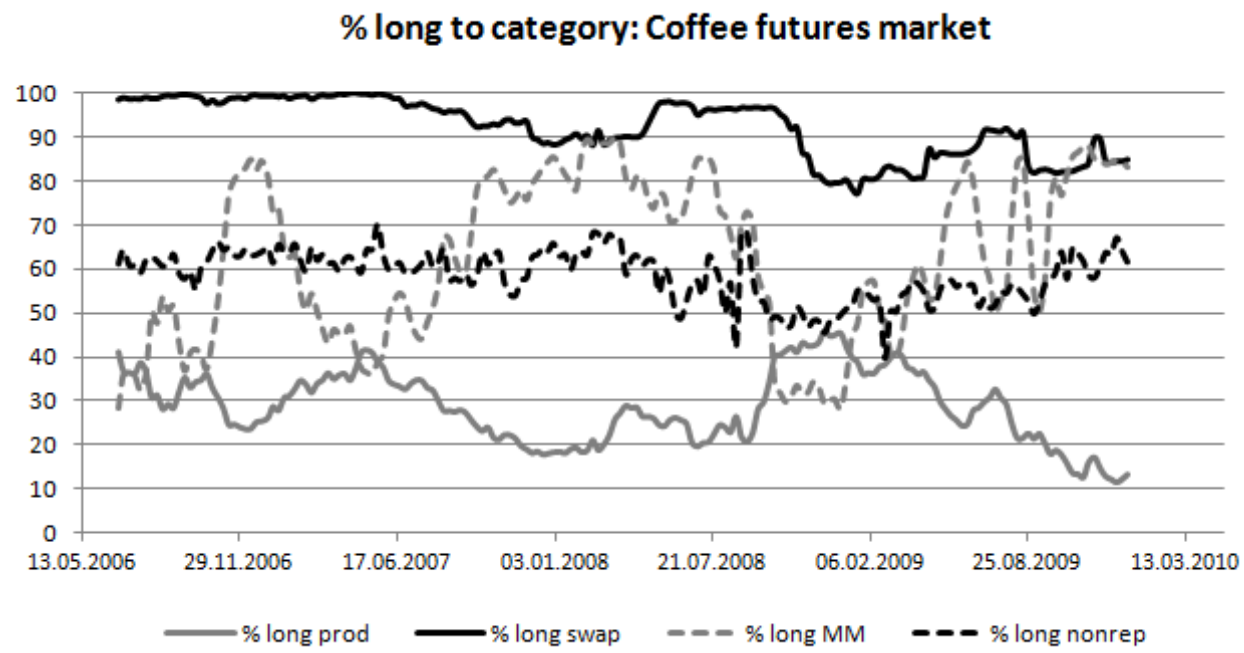

Figure 3.5: Breakdown of the Percentage Long for each Category for the Coffee Futures Market 


\begin{tabular}{|c|c|c|c|c|c|c|}
\hline \multicolumn{7}{|c|}{ \% Long correlation charts } \\
\hline Corn futures & & Corn price & Prod./Merchant & $\begin{array}{c}\text { Swap } \\
\text { Dealer }\end{array}$ & $\begin{array}{c}\text { Money } \\
\text { Manager }\end{array}$ & $\begin{array}{c}\text { Non- } \\
\text { reportable }\end{array}$ \\
\hline Category & Type & & Hedge & Hedge & Speculate & $?$ \\
\hline \multicolumn{7}{|l|}{ Corn price } \\
\hline Monday & & 1.00 & & & & \\
\hline Prod./Merchant & Hedge & -0.48 & 1.00 & & & \\
\hline Swap Dealer & Hedge & -0.12 & -0.55 & 1.00 & & \\
\hline Money Manager & Speculate & 0.51 & -0.82 & 0.42 & 1.00 & \\
\hline Non-reportable & $?$ & 0.19 & 0.08 & 0.17 & -0.11 & 1.00 \\
\hline $\begin{array}{l}\text { Natural gas } \\
\text { futures }\end{array}$ & & $\begin{array}{c}\text { Natural gas } \\
\text { price }\end{array}$ & Prod./Merchant & $\begin{array}{c}\text { Swap } \\
\text { Dealer }\end{array}$ & $\begin{array}{c}\text { Money } \\
\text { Manager }\end{array}$ & $\begin{array}{c}\text { Non- } \\
\text { reportable }\end{array}$ \\
\hline Category & Type & & Hedge & Hedge & Speculate & $?$ \\
\hline NG price Monday & & 1.00 & & & & \\
\hline Prod./Merchant & Hedge & 0.28 & 1.00 & & & \\
\hline Swap Dealer & Hedge & 0.91 & 0.53 & 1.00 & & \\
\hline Money Manager & Speculate & -0.88 & -0.52 & -0.95 & 1.00 & \\
\hline Non-reportable & $?$ & 0.09 & 0.15 & 0.16 & -0.16 & 1.00 \\
\hline $\begin{array}{l}\text { Live Cattle } \\
\text { futures }\end{array}$ & & $\begin{array}{c}\text { Live Cattle } \\
\text { price }\end{array}$ & Prod./Merchant & $\begin{array}{c}\text { Swap } \\
\text { Dealer }\end{array}$ & $\begin{array}{c}\text { Money } \\
\text { Manager }\end{array}$ & $\begin{array}{c}\text { Non- } \\
\text { reportable }\end{array}$ \\
\hline Category & Type & & Hedge & Hedge & Speculate & $?$ \\
\hline NG price Monday & & 1.00 & & & & \\
\hline Prod./Merchant & Hedge & 0.38 & 1.00 & & & \\
\hline Swap Dealer & Hedge & -0.31 & 0.27 & 1.00 & & \\
\hline Money Manager & Speculate & -0.73 & -0.48 & 0.32 & 1.00 & \\
\hline Non-reportable & $?$ & 0.22 & 0.62 & 0.16 & -0.23 & 1.00 \\
\hline Copper futures & & Copper price & Prod./Merchant & $\begin{array}{l}\text { Swap } \\
\text { Dealer }\end{array}$ & $\begin{array}{c}\text { Money } \\
\text { Manager }\end{array}$ & $\begin{array}{c}\text { Non- } \\
\text { reportable }\end{array}$ \\
\hline Category & Type & & Hedge & Hedge & Speculate & $?$ \\
\hline NG price Monday & & 1.00 & & & & \\
\hline Prod./Merchant & Hedge & -0.36 & 1.00 & & & \\
\hline Swap Dealer & Hedge & 0.10 & -0.24 & 1.00 & & \\
\hline Money Manager & Speculate & 0.14 & -0.58 & -0.53 & 1.00 & \\
\hline Non-reportable & $?$ & -0.19 & -0.57 & 0.16 & 0.28 & 1.00 \\
\hline Coffee futures & & Coffee price & Prod./Merchant & $\begin{array}{c}\text { Swap } \\
\text { Dealer }\end{array}$ & $\begin{array}{c}\text { Money } \\
\text { Manager }\end{array}$ & $\begin{array}{c}\text { Non- } \\
\text { reportable }\end{array}$ \\
\hline Category & Type & & Hedge & Hedge & Speculate & $?$ \\
\hline NG price Monday & & 1.00 & & & & \\
\hline Prod./Merchant & Hedge & -0.40 & 1.00 & & & \\
\hline Swap Dealer & Hedge & -0.51 & 0.02 & 1.00 & & \\
\hline Money Manager & Speculate & 0.54 & -0.88 & -0.25 & 1.00 & \\
\hline Non-reportable & $?$ & -0.15 & -0.48 & 0.38 & 0.36 & 1.00 \\
\hline
\end{tabular}

Figure 4.1 Correlation Chart (Percentage Long per Category) for the Five Futures Markets

The data set used is the disaggregate data 2006-2009 
Table 5.1 Dickey-Fuller Test for Commodity Futures Prices and Percentage Holdings per Category

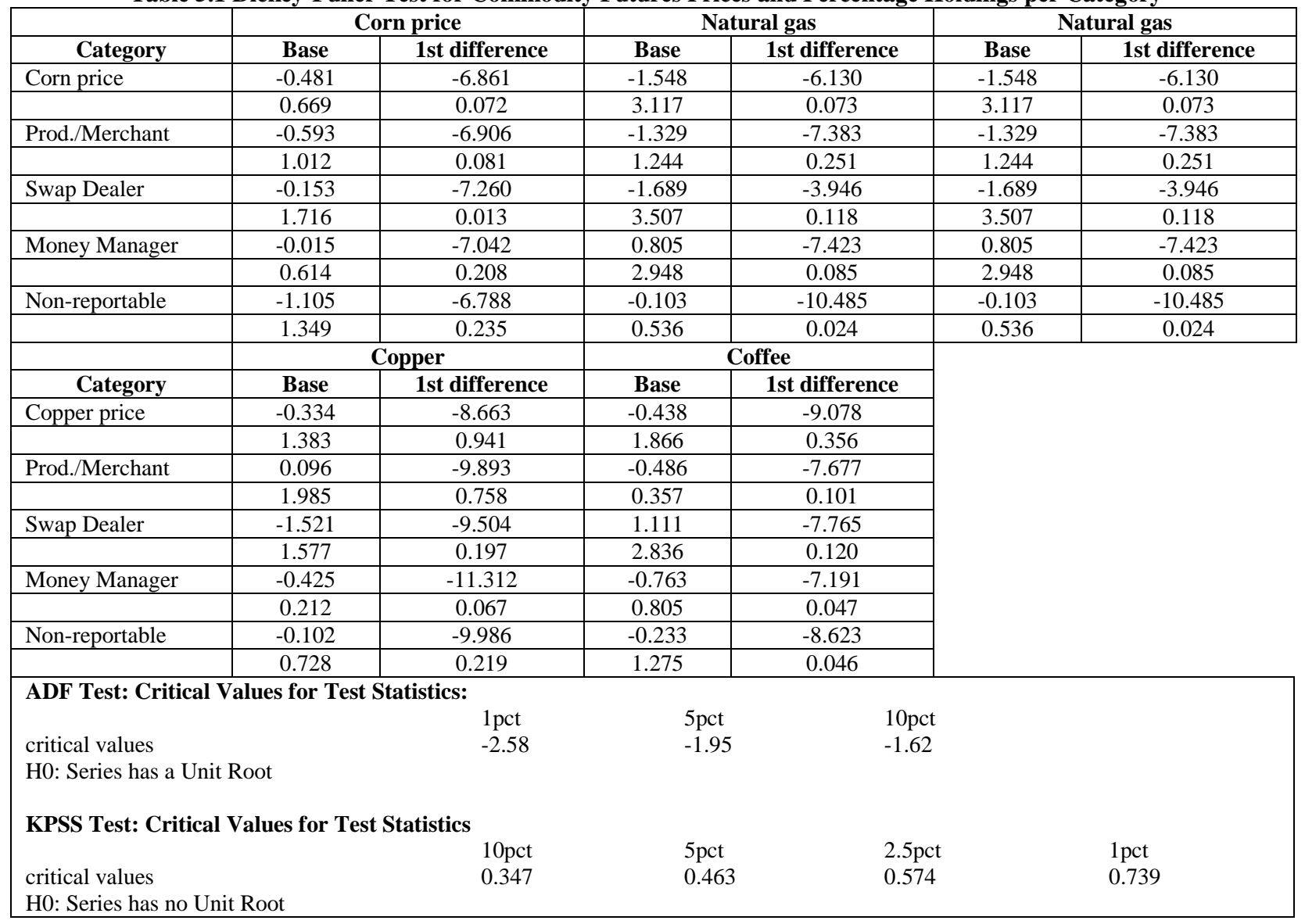

Table 6.1 Granger Test for the Price Change and the Change in Net Position between the COT Reports

The observations go weekly Tuesday-Tuesday

\begin{tabular}{|c|c|c|c|c|c|c|c|c|}
\hline N = No Granger & $\begin{array}{r}\text { Grange } \\
\text { sality, Y }\end{array}$ & $\begin{array}{l}\text { nalysis of } \\
\text { ausality } \\
\text { ranger C }\end{array}$ & $\begin{array}{l}\text { Disaggre } \\
\text { (for "Gr } \\
\text { ality, (p-y }\end{array}$ & $\begin{array}{l}\text { Commit } \\
\text { r Causal } \\
\end{array}$ & $\begin{array}{l}\text { trof Trade } \\
\text { from Tue }\end{array}$ & $\begin{array}{l}\text { ata: } \\
\text { ay-Tuesd }\end{array}$ & & \\
\hline & Produce & Ierchant & Swa & ealer & Money & anager & Non & orting \\
\hline & $\begin{array}{c}\Delta \text { pos } \rightarrow \\
\Delta p\end{array}$ & $\begin{array}{c}\Delta \mathbf{p} \rightarrow \\
\Delta \text { pos }\end{array}$ & $\begin{array}{c}\Delta \operatorname{pos} \rightarrow \\
\Delta \mathrm{p}\end{array}$ & $\begin{array}{c}\Delta \mathbf{p} \rightarrow \\
\Delta \text { pos }\end{array}$ & $\begin{array}{c}\Delta \mathrm{pos} \rightarrow \\
\Delta \mathrm{p}\end{array}$ & $\begin{array}{c}\Delta \mathbf{p} \rightarrow \\
\Delta \text { pos }\end{array}$ & $\begin{array}{c}\Delta \operatorname{pos} \rightarrow \\
\Delta \mathbf{p}\end{array}$ & $\underset{\Delta \mathbf{p} \rightarrow}{\Delta}$ \\
\hline $\begin{array}{l}\text { Natural gas } \\
\text { Immediately } \\
\text { (Last Tue - Tue) } \\
\text { Corn }\end{array}$ & $\begin{array}{c}\mathrm{N} \\
(0.623)\end{array}$ & $\begin{array}{c}\mathrm{N} \\
(0.839)\end{array}$ & $\begin{array}{c}\mathrm{N} \\
(0.076)\end{array}$ & $\begin{array}{c}\mathrm{N} \\
(0.407)\end{array}$ & $\begin{array}{c}\mathrm{N} \\
(0.523)\end{array}$ & $\begin{array}{c}\mathrm{N} \\
(0.806)\end{array}$ & $\begin{array}{c}\mathrm{N} \\
(0.698)\end{array}$ & $\begin{array}{c}\mathrm{N} \\
(0.471)\end{array}$ \\
\hline $\begin{array}{l}\text { Immediately } \\
\text { (Last Tue - Tue) }\end{array}$ & $\begin{array}{c}\mathrm{N} \\
(0.363)\end{array}$ & $\begin{array}{c}\mathrm{N} \\
(0.470)\end{array}$ & $\begin{array}{c}\mathrm{N} \\
(0.397)\end{array}$ & $\begin{array}{c}\mathrm{Y} \\
(0.000)\end{array}$ & $\begin{array}{c}\mathrm{N} \\
(0.298)\end{array}$ & $\begin{array}{c}\mathrm{N} \\
(0.808)\end{array}$ & $\begin{array}{c}\mathrm{N} \\
(0.592)\end{array}$ & $\begin{array}{c}\mathrm{Y} \\
(0.000)\end{array}$ \\
\hline $\begin{array}{l}\text { Live Cattle } \\
\text { (Last Tue - Tue) } \\
\text { Copper }\end{array}$ & $\begin{array}{c}\mathrm{Y} \\
(0.032)\end{array}$ & $\begin{array}{c}\mathrm{N} \\
(0.161)\end{array}$ & $\begin{array}{c}\mathrm{N} \\
(0.184)\end{array}$ & $\begin{array}{c}\mathrm{N} \\
(0.435)\end{array}$ & $\begin{array}{c}\mathrm{Y} \\
(0.025)\end{array}$ & $\begin{array}{c}\mathrm{N} \\
(0.337)\end{array}$ & $\begin{array}{c}\mathrm{N} \\
(0.761)\end{array}$ & $\begin{array}{c}\mathrm{N} \\
(0.729)\end{array}$ \\
\hline $\begin{array}{l}\text { Immediately } \\
\text { (Last Tue - Tue) } \\
\text { Coffee }\end{array}$ & $\begin{array}{c}\mathrm{N} \\
(0.096)\end{array}$ & $\begin{array}{c}\mathrm{Y} \\
(0.036)\end{array}$ & $\begin{array}{c}\mathrm{N} \\
(0.636)\end{array}$ & $\begin{array}{c}\mathrm{N} \\
(0.518)\end{array}$ & $\begin{array}{c}\mathrm{N} \\
(0.178)\end{array}$ & $\begin{array}{c}\mathrm{N} \\
(0.263)\end{array}$ & $\begin{array}{c}\mathrm{N} \\
(0.883)\end{array}$ & $\begin{array}{c}\mathrm{Y} \\
(0.014)\end{array}$ \\
\hline $\begin{array}{l}\text { Immediately } \\
\text { (Last Tue - Tue) }\end{array}$ & $\begin{array}{c}\mathrm{N} \\
(0.174)\end{array}$ & $\begin{array}{c}\mathrm{Y} \\
(0.001)\end{array}$ & $\begin{array}{c}\mathrm{N} \\
(0.474)\end{array}$ & $\begin{array}{c}\mathrm{N} \\
(0.767)\end{array}$ & $\begin{array}{c}\mathrm{N} \\
(0.081)\end{array}$ & $\begin{array}{c}\mathrm{Y} \\
(0.000)\end{array}$ & $\begin{array}{c}\mathrm{N} \\
(0.584)\end{array}$ & $\begin{array}{c}\mathrm{Y} \\
(0.007)\end{array}$ \\
\hline
\end{tabular}


Table 7.1 Granger Test for Change in Price and Percentage Long Holdings per Category for each Commodity Futures Market Analysis of the Disaggregate Commitments of Traders Data:

\begin{tabular}{|c|c|c|c|c|c|c|c|c|c|}
\hline N $=$ No Gran & r Causality, $Y=$ & $\begin{array}{r}\text { Gran } \\
\text { ranger Causalit }\end{array}$ & $\begin{array}{l}\text { Analysi } \\
\text { r Causality Test } \\
\text { (p-value) }\end{array}$ & $\begin{array}{l}\text { f the Disaggregat } \\
\text { or "Granger Ca }\end{array}$ & $\begin{array}{l}\text { Commitments } \\
\text { ality" on Day }\end{array}$ & $\begin{array}{l}\text { aders Data: } \\
\text { ind } 3 \text { after Data }\end{array}$ & eleased)* & & \\
\hline Commodity & $\begin{array}{c}\text { Producer/ } \\
\text { Merchant } \\
\Delta \% \text { long }->\Delta \mathbf{p}\end{array}$ & $\begin{array}{c}\text { Swap Dealer } \\
\Delta \% \text { long }->\Delta \mathbf{p}\end{array}$ & $\begin{array}{c}\text { Money } \\
\text { Manager } \\
\Delta \% \text { long }->\Delta p\end{array}$ & $\begin{array}{l}\text { Non-reporting } \\
\Delta \% \text { long }->\Delta \mathbf{p}\end{array}$ & & $\begin{array}{c}\text { Producer/ } \\
\text { Merchant } \\
\Delta \% \text { long }->\Delta \mathbf{p}\end{array}$ & $\begin{array}{c}\text { Swap Dealer } \\
\Delta \% \text { long }->\Delta p\end{array}$ & $\begin{array}{c}\text { Money } \\
\text { Manager } \\
\Delta \% \text { long -> } \Delta \mathbf{p}\end{array}$ & $\begin{array}{l}\text { Non-reporting } \\
\Delta \% \text { long -> } \Delta \mathbf{p}\end{array}$ \\
\hline Natural gas & & & & & Corn & & & & \\
\hline 3 days after & $\mathrm{N}$ & $\mathrm{N}$ & $\mathrm{N}$ & $\mathrm{N}$ & 3 days after & $\mathrm{N}$ & $\mathrm{Y}$ & $\mathrm{N}$ & $\mathrm{N}$ \\
\hline (Fri-Wed) & $(0.867)$ & $(0.240)$ & $(0.804)$ & $(0.372)$ & (Fri-Wed) & $(0.225)$ & $(0.011)$ & $(0.475)$ & (0.664) \\
\hline 2 days after & $\mathrm{N}$ & $\mathrm{N}$ & $\mathrm{N}$ & $\mathrm{N}$ & 2 days after & $\mathrm{N}$ & $\mathrm{N}$ & $\mathrm{N}$ & $\mathrm{N}$ \\
\hline (Fri-Tue) & $(0.491)$ & $(0.207)$ & $(0.623)$ & $(0.365)$ & (Fri-Tue) & $(0.737)$ & $(0.207)$ & $(0.772)$ & (0.109) \\
\hline 1 Day & $\mathrm{N}$ & $\mathrm{N}$ & Y & $\mathrm{N}$ & 1 Day After & $\mathrm{N}$ & $\mathrm{N}$ & $\mathrm{N}$ & $\mathrm{N}$ \\
\hline $\begin{array}{l}\text { After release } \\
\text { (Fri-Mon) }\end{array}$ & $(0.793)$ & $(0.175)$ & $(0.037)$ & $(0.732)$ & $\begin{array}{l}\text { release } \\
\text { (Fri-Mon) }\end{array}$ & $(0.844)$ & $(0.895)$ & $(0.585)$ & $(0.756)$ \\
\hline Live Cattle & & & & & Coffee & & & & \\
\hline 3 days after & $\mathrm{N}$ & $\mathrm{N}$ & $\mathrm{N}$ & $\mathrm{N}$ & 3 days after & $\mathrm{N}$ & $\mathrm{N}$ & $\mathrm{N}$ & $\mathrm{N}$ \\
\hline (Fri-Wed) & $(0.893)$ & $(0.139)$ & $(0.282)$ & $(0.243)$ & (Fri-Wed) & $(0.183)$ & $(0.545)$ & $(0.879)$ & (0.938) \\
\hline 2 days after & $\mathrm{N}$ & $\mathrm{N}$ & $\mathrm{N}$ & $\mathrm{N}$ & 2 days after & $\mathrm{N}$ & $\mathrm{N}$ & $\mathrm{N}$ & $\mathrm{N}$ \\
\hline (Fri-Tue) & $(0.889)$ & (0.991) & $(0.343)$ & $(0.052)$ & (Fri-Tue) & $(0.267)$ & $(0.960)$ & $(0.343)$ & $(0.5455)$ \\
\hline 1 Day & $\mathrm{N}$ & $\mathrm{N}$ & $\mathrm{N}$ & $\mathrm{N}$ & 1 Day After & $\mathrm{N}$ & $\mathrm{N}$ & $\mathrm{N}$ & $\mathrm{N}$ \\
\hline After release & N & 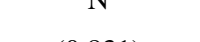 & & & release & & & & \\
\hline (Fri-Mon) & $(0.330)$ & $(0.831)$ & (0.449) & $(0.878)$ & (Fri-Mon) & $(0.068)$ & (0.895) & $(0.448)$ & $(0.650)$ \\
\hline Copper & & & & & & & & & \\
\hline 3 days after & $\mathrm{N}$ & $\mathrm{N}$ & $\mathrm{N}$ & $\mathrm{N}$ & & & & & \\
\hline (Fri-Wed) & $(0.956)$ & $(0.547)$ & $(0.165)$ & $(0.664)$ & & & & & \\
\hline 2 days after & $\mathrm{N}$ & $\mathrm{N}$ & $\mathrm{N}$ & $\mathrm{N}$ & & & & & \\
\hline (Fri-Tue) & $(0.593)$ & $(0.236)$ & $(0.137)$ & $(0.702)$ & & & & & \\
\hline 1 Day After & & & & & & & & & \\
\hline release & $\mathrm{N}$ & $\mathrm{Y}$ & $\mathrm{N}$ & $\mathrm{N}$ & & & & & \\
\hline (Fri-Mon) & $(0.664)$ & $(0.043)$ & $(0.830)$ & $(0.586)$ & & & & & \\
\hline
\end{tabular}

